\title{
Protective effects of Urtica dioica L. seed extract on liver tissue injury and antioxidant capacity in irradiated rats
}

\author{
Kenan Yıldızhan ${ }^{\circledR 1}$, Ömer Can Demirtaş², Ahmet Uyar ${ }^{3}$, Zübeyir Huyut ${ }^{4 *}$, Tahir Çakir ${ }^{1}$, \\ Ömer Faruk Keleş ${ }^{5}$ Zabit Yener $^{5}$
}

\begin{abstract}
${ }^{I}$ Department of Biophysics, Medical Faculty, Van Yuzuncu Yll University, Van, Turkey, ${ }^{2}$ Department of Biophysics, Medical Faculty, Gaziantep University, Gaziantep, Turkey, ${ }^{3}$ Department of Pathology, Faculty of Veterinary, Mustafa Kemal University, Hatay, Turkey, ${ }^{4}$ Department of Biochemistry, Medical Faculty, Van Yuzuncu Yll University, Van, Turkey, ${ }^{5}$ Department of Pathology, Faculty of Veterinary, Van Yuzuncu Yll University, Van, Turkey
\end{abstract}

\begin{abstract}
Radiotherapy is often used for the treatment of cancer. However, it causes some side effects in patients. This study aimed to determine the hepatoprotective effects of Urtica dioica L. seed-extract (UDSE) in radiation-induced liver injury. Thirty-two male rats were randomly divided into 4 groups $(n=8)$ : control(C) group: no action was taken; radiation (R) group: irradiation was administrated at $5 \mathrm{~Gy}$ singlefraction, radiation with UDSE(R+UDSE) group: irradiation was administrated at 5 Gy single-fraction and animals were fed pellets with $30 \mathrm{~mL}$ UDSE/kg; UDSE group: animals were fed pellets with $30 \mathrm{~mL}$ UDSE $/ \mathrm{kg}$. All of the experiments were performed in all of the groups over 10 days. Malondialdehyde (MDA) and reduced-glutathione (GSH) levels and superoxide-dismutase (SOD), catalase (CAT), glutathione-peroxidase (GSH-Px), aspartate-transaminase (AST), and alanine-aminotransferase (ALT) activities were determined. Histopathological findings were also evaluated in liver tissues. SOD, CAT and GSH-Px activities and GSH levels in the serum and liver were significantly increased, while MDA levels decreased in the R+UDSE group compared with the $\mathrm{R}$ group $(\mathrm{P}<0.05)$. Moreover, AST and ALT serum activities in the $\mathrm{R}+\mathrm{UDSE}$ group were lower than those in the $\mathrm{R}$ group $(\mathrm{P}<0.05)$. In addition, radiation induced degenerative/necrotic changes in the $\mathrm{R}$ group were significantly compensated in the $\mathrm{R}+\mathrm{UDSE}$ group. The results showed that radiation increased oxidative stress and decreased antioxidant capacity, as well as degeneration in the liver. However, UDSE attenuated these degenerative changes.
\end{abstract}

Keywords: Radiation. Urtica dioica L. seed extract. Oxidative stress. Antioxidant. Tissue injury.

\section{INTRODUCTION}

Every year, almost 14 million new cancer cases are diagnosed worldwide, and most of these patients utilize radiotherapy as a treatment or a strategy to relieve their pain (Jaffray, Gospodarowicz, 2015). Radiotherapy aims to destroy cancer cells by targeting the maximum radiation dose at the tumour tissue (Perez, Fields, 1987). The first aim of radiotherapy is to damage DNA in tumour cells to prevent uncontrolled replication and division mechanisms (Taysi et al., 2008). However, it is known that this also negatively affects non-target tissues. In addition, the dose increments and the localization of tumours in providing local tumour control are associated with complications in

\footnotetext{
*Correspondence: Z. Huyut. Department of Biochemistry, Faculty of Medicine, Van Yuzuncu Y1l University, 65080,Van, Turkey. Phone: +90 432225 17 01-05

/ Fax:+90 432236 1054. E-mail: zubeyir.huyut@gmail.com
}

normal tissues. Therefore, radiation tolerance of non-target cells plays an important role in tumour control and cancer treatment (Perez, Fields, 1987).

Radiotherapy not only leads to DNA damage but also triggers the formation of free radicals through indirect mechanisms (Taysi et al., 2008). Radiation results in the breakdown of water molecules in the body to form free oxygen radicals such as hydroxyl radicals $(\mathrm{OH} \bullet)$ and superoxide $\left(\mathrm{O}_{2}{ }^{--}\right)$during radiotherapy. It also leads to a distortion of the oxidant and antioxidant balance in the cells (Alizadeh et al., 2013). Reactive oxygen species (ROS) are responsible for the formation of adverse situations such as carcinogenesis, mutagenesis, ageing and atherosclerosis (Halliwel, 1989). Antioxidants have an important role in cancer treatment and complementary or preventive medicine, although they are still controversial in this field (Song, Yan, Chai, 2006). 
Nettle (Urtica dioica L.) (UD) is one of the most widely used plants in alternative medicine in Turkey, because of its therapeutic properties (Kav et al., 2008). Nettle seeds contain $26.4 \%$ nitrogen-free extract, $25 \%$ fat, $21.9 \%$ protein, $11.4 \%$ fibre $8.5 \%$ water, and $6.8 \%$ ash (Kavalali, Oztekin-Mat, 1996). Research has also reported that Urtica dioica L. seed extract (UDSE) has antioxidant properties, as well as immunomodulatory, antiinflammatory, antimicrobial, and pharmacological effects in in vitro and in vivo studies (Gulçin et al., 2004; Hajhashemi, Klooshani, 2013). Although the therapeutic effects of UDSE have been shown in some experimental studies, there are no reports about the protective role of UDSE against the formed tissue damage due to ionizing radiation (Yener et al., 2009; Körpe et al., 2013; Telo, Halifeoglu, Özercan, 2017). Determination of the inhibitory effects of UDSE on free radical generation will be important in patients receiving radiotherapy.

In this study, we aimed to investigate the protective effects of UDSE on liver tissue damage and selected antioxidant enzyme activities in irradiated rats. Therefore, we evaluated the serum activities of aspartate transaminase (AST), alanine transaminase (ALT) and intracellular antioxidant enzymes such as superoxide dismutase (SOD), glutathione peroxidase (GSH-Px) and catalase (CAT), as well as the levels of reduced glutathione (GSH) and lipid peroxidation product malondialdehyde (MDA) in liver tissue and serum samples. In addition, the pathological effects of radiation in the liver tissue samples in all of the groups were also histomorphologically examined.

\section{MATERIAL AND METHODS}

\section{Experimental design and study groups}

Thirty-two male Wistar albino rats with a body weight of 180-200 grams and aged 8 weeks, were used. The present study was performed in accordance with the Van Yuzuncu Y1l University Experimental Animals Local Ethics Committee regulations and animal care and rights policies (28.07.2016, decision number: 07). The rats were quarantined for at least 7 days before irradiation and fed standard chow and water at a standard temperature $\left(22 \pm 1^{\circ} \mathrm{C}\right)$ and light conditions ( $12 \mathrm{~h} \mathrm{light} / 12 \mathrm{~h}$ dark $)$ in a windowless laboratory room. The rats were randomly divided into 4 groups $(n=8)$ : the control $(C)$ group was fed standard pellets for 10 days, the radiation $(\mathrm{R})$ group was fed standard pellets for 10 days after irradiation with a 5 Gy single fraction, the radiation with UDSE (R+UDSE) group was exposed to 5 Gy radiation as a single fraction and fed pellets with $30 \mathrm{~mL}$ UDSE/ $\mathrm{kg}$ for 10 days, and the
UDSE group was fed pellets with $30 \mathrm{~mL}$ UDSE/kg for 10 days.

\section{Plant materials and extraction procedure}

The UDSE were purchased from a local herb store (Van, Turkey) and the species description was identified by biologist Kenan Yildizhan (who has a master's degree in botany). Voucher specimens were preserved in herbarium of the Department of Biology, Faculty of Sciences, at Van Yuzuncu Y1l University (Herbarium code: VANF-16778).

The seed extract was prepared by partially modifying the method used by Yener et al. (2009). Nettle seed (Urtica dioica L. seed) was used as the plant material. For extraction, the plant seeds were ground in an electric mill. One kilogram of the milled seeds was placed in a glass beaker and $2 \mathrm{~L}$ ethanol $(80 \%)$ was added. The beaker was covered with aluminium foil and the milled seeds were homogenized on a shaker for $24 \mathrm{~h}$. The homogenized mixture was poured through the filter and the supernatant was pipetted into a tube (volume: $10 \mathrm{~mL}$ ). Next, supernatant was centrifuged for $5 \mathrm{~min}$ at $3500 \mathrm{xg}$. The supernatant was poured through a $0.45 \mu \mathrm{m}$ hydrophilic filter (millipore) with the aid of an injector. This process was repeated at least twice, and all of the supernatants were placed in the same container. Then, $400 \mathrm{~mL}$ of the filtrate was placed in the evaporator and purified from the solvent at $37^{\circ} \mathrm{C}$ for aproximately $1 \mathrm{~h}$ and $40 \mathrm{~min}$. At the end of the process, the condensed extract was placed in the falcon tubes and stored at - 20 ${ }^{\circ} \mathrm{C}$ in the freezer. At the beginning of the study, the UDSE was mixed with the milled pellet $(30 \mathrm{~mL} / \mathrm{kg})$. The mix was compressed and dried, and the indicated groups were fed this mixed pellet food.

\section{Irradiation process}

First, a preliminary study was carried out for the application procedure. The optimal radiation dose distribution was set as $5 \mathrm{~Gy}$ on a rat that had the same physiological conditions. Radiation application to the rats was performed with a SiemensTM brand Sensation4 model CT-simulator device and total body CT images (2.5 mm section thickness) were obtained in the prone position after being anaesthetized with $50 \mathrm{mg} / \mathrm{kg}$, IP (intraperitoneal) ketamine. These cross-sectional images were transferred to a ProwessTM brand three-dimensional (3-D) radiotherapy treatment planning system, allowing for contouring of all of the rat's tissues and organs. After the contouring process was finished, the rat's whole body 3-D dose plan was applied using 6-MV energized photons 
from 2 areas of equal weight to obtain a single fraction of radiation of $5 \mathrm{~Gy}$ in the liver while the total body was irradiated. Irradiation was performed at gantry angles of 00 and 180 degrees with equal dose weights on the front and back sides. This dose schedule was designed to be the same for all of the rats and the planned dose procedure was sent to the SiemensTM Artiste (160 MLC) model linac for total body irradiation (Figure 1).

\section{Preparation of the supernatant from the liver tissue samples and obtaining the serum samples}

All of the rat groups were anaesthesied with $50 \mathrm{mg} / \mathrm{kg}$ IP ketamine at the end of day 10. Whole blood was collected via intracardiac injection, transferred into biochemistry tubes, and centrifuged at $3500 \times \mathrm{g}$ for $10 \mathrm{~min}$.
The serum was carefully transferred using a dropper. In addition, $1 \mathrm{~g}$ of liver tissue was homogenized using a homogenizer (Ultra Turrax-T25) in $9 \mathrm{~mL} 20 \mathrm{mM}$ Tris$\mathrm{HCl}(\mathrm{pH}: 7.4, \mathrm{~g} / \mathrm{V}, 1 / 10$ ratio) as a previously described (Gumustekin et al., 2010). Next, homogenized liver tissue was centrifuged at $15000 \times \mathrm{g}$ and $4{ }^{\circ} \mathrm{C}$ for $30 \mathrm{~min}$. The upper phase was transferred into tubes and stored at $-80^{\circ} \mathrm{C}$ until the biochemical analysis was performed.

\section{Biochemical analysis}

Measurement of the MDA levels from the serum and liver tissue samples was carried out using a fluorescence detector at $527 \mathrm{~nm}$ for excitation and $551 \mathrm{~nm}$ for emission wavelengths in a high performance liquid chromatography device (Agilent 1200 series from Germany), according to
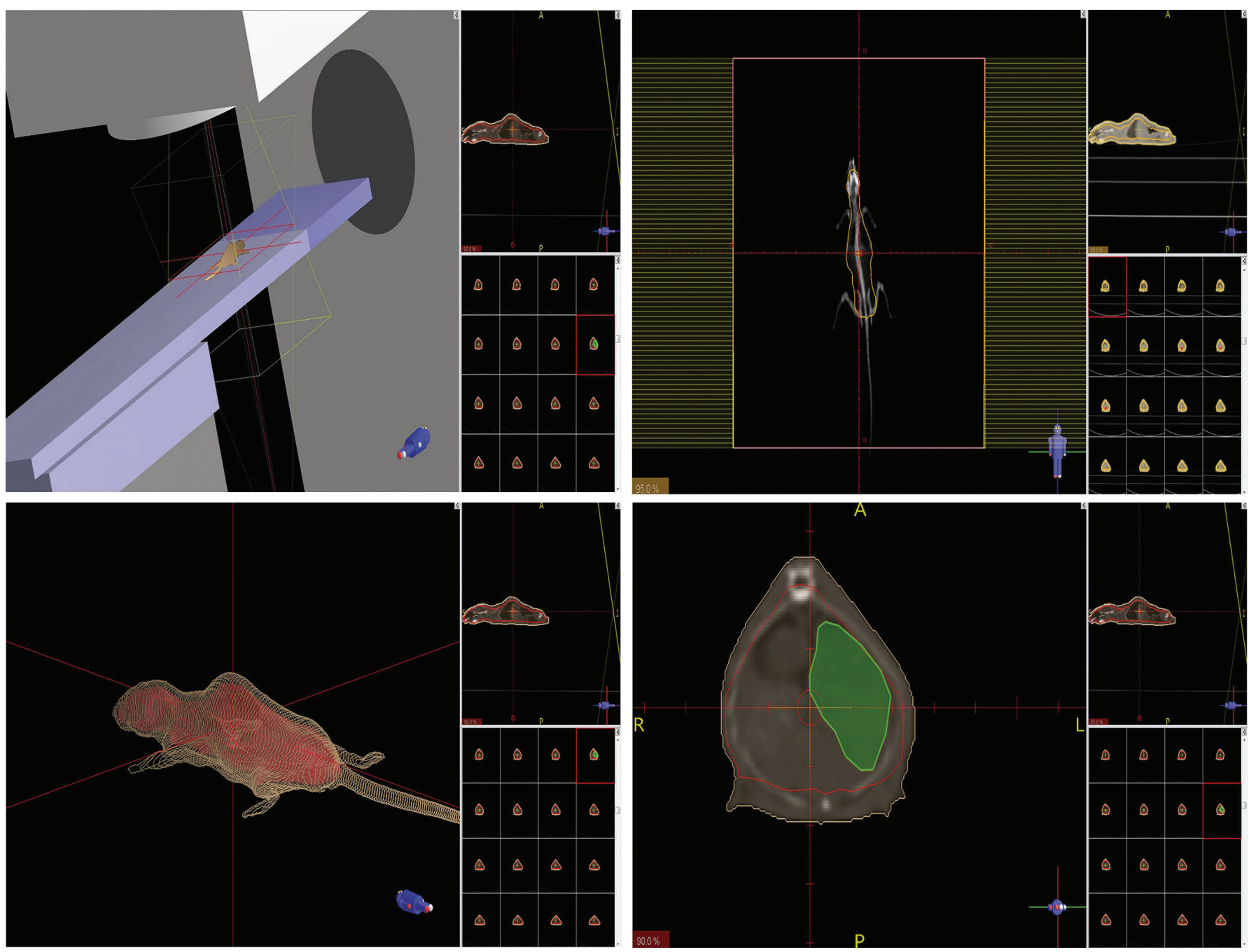

FIGURE 1 - Rat whole body three-dimensional (3-D) dose planning. Gantry 00 degrees beam angle and rat position. b) Irradiation field on the rat. c) 3-D radiation dose (5Gy) distribution on the rat. d) Contouring of the rat tissues and organs (green colored area: liver) in axial cross-sectional CT image (red line: field containing 5 Gy radiation dose). After the calculation of the radiation dose, the rats were placed and irradiated by a Linear Particle Accelerator SiemensTM Artiste (160 MLC) model LINAC using X-rays. 
the previously described method by Khoschsorur et al. (2000). A RP18 column was used $(150 \times 4.6 \mathrm{~mm}$ length and $5 \mu \mathrm{m}$ particle size) for the experiments. For the mobile phase, a mixture of $50 \mathrm{mM}$ phosphate buffer (400 mL, pH: 6.8) and $600 \mathrm{~mL}$ pure methanol was used. GSH-Px activity was determined by the previous method of Valentine and Paglia (1983). Decreased absorbance values were recorded at intervals of $30 \mathrm{sec}$ at $340 \mathrm{~nm}$ for $3 \mathrm{~min}$. CAT activity was measured at $405 \mathrm{~nm}$ on a spectrophotometer (Shimadzu UV mini 1240, Japan) using the Goth colorimetric method (Goth, 1991). Cu and Zn-coupled SOD activities in the liver supernatant and serum were determined spectrophotometrically at $560 \mathrm{~nm}$ using the colorimetric method based on the rate of nitroblue tetrazolium inhibition (Sun, Oberley, Li, 1988). The activities were calculated by comparison with the standard curve. SOD activity in the tissue samples was expressed as IU/mg protein. In the serum samples, measurement was performed in accordance with the prospectus of the commercial kit (Rel Assay Diagnostics ${ }^{T M}$ ). The AST and ALT activities were measured in an Architect c8000 Clinical Chemistry Analyzer. The obtained values were expressed as IU/mL.

\section{Histopathological examination}

At the end of the necropsy, the liver tissues for histopathological evaluation were fixed in a $10 \%$ formalin solution for $48 \mathrm{~h}$. After conduction routine processes for tissue tracking, the liver tissues were embedded in paraffin blocks. Sections $4 \mu \mathrm{m}$ thick were taken from each block and prepared on slides. The sections were stained with haematoxylin-eosin (HE) for histopathologic examination and visualized by light microscopy (Nikon Eclipse 80i-DS-Ri2). A scoring system was used in the obtained micrograph images to evaluate the radiation damage in the liver. According to this, all of the liver sections were examined for degeneration, necrosis and proliferation of the perisinusoidal cells by a board certified pathologist blinded to the treatment groups and then scored. Scoring was defined as slight and moderate, as shown in Table III.

\section{Statistical analysis}

All of the results were expressed as the mean \pm standard deviation (SD). Following the Kruskal Wallis analysis, a post hoc (Tukey's) test was performed to identify the different groups. Data were analysed using SPSS (version 20, Inc., Chicago, Illinois). P values of 0.05 or less were considered statistically significant.

\section{RESULTS AND DISCUSSION}

Clinical studies have shown that radiation increases the level of oxidant molecules and reduces the activity of antioxidants such as SOD, CAT, and GSH, even if used in cancer diagnostics and treatment (Srinivasan et al., 2009). Therefore, to ensure tumour control, the side effects to healthy tissues after the applied dose increments must also be considered (Kushi et al., 2006). Plants containing natural antioxidants have been widely used in the past. Because of the harmful effects of synthetic antioxidants, natural antioxidants and plants have become the focus with increased interest. It was reported that UD extract possesses effective antioxidant properties and inhibits peroxidation (Lou et al., 1999). UD seeds include phytochemicals such as flavonoids, which have been shown to be effective against scavenger free radicals (Akbay et al., 2003). In this study, the protective effects of UDSE on serum and liver tissue were investigated in irradiated rats for the first time.

In this study, there were no significant differences between the weight averages of the rats in any of the groups.

\section{Biochemical findings}

Serum AST activities were significantly different in all of the groups $(\mathrm{p}<0.05)$. The lowest AST activities were observed in the UDSE group, whereas the highest activities were determined in the $\mathrm{R}$ group. In addition, the AST activities of the UDSE and R+UDSE groups were lower than those in the $\mathrm{R}$ group $(\mathrm{P}<0.001)$.

When the serum ALT activities were examined, the $\mathrm{R}$ group values were higher than those in the other groups $(\mathrm{P}<0.05)$. Additionally, the serum ALT activities of the $\mathrm{R}+\mathrm{UDSE}$ and UDSE groups were lower than those of the $\mathrm{R}$ group $(\mathrm{P}<0.001$, Table I).

The MDA and GSH levels, and the SOD, CAT, and GSH-Px enzyme activities in the serum and liver tissue samples of the experimental groups are shown in Tables I and II. The MDA levels in the serum and liver tissue samples were higher in the $\mathrm{R}$ group $(\mathrm{P}<0.05)$ than those in the other groups. However, there was no sitatistically significant differences among the MDA levels in the liver tissue samples of the $\mathrm{C}, \mathrm{R}+\mathrm{UDSE}$, and UDSE groups $(P>0.05)$. In addition, the serum MDA levels of the $C$ and UDSE groups were lower than those of the R and $\mathrm{R}+$ UDSE groups $(\mathrm{P}<0.05)$.

Membrane lipids are more sensitive to the deleterious effects of free radicals. MDA is a major oxidation product of peroxidized polyunsaturated fatty acids and 
an increased MDA content is an important indicator of lipid peroxidation (Huyut et al., 2016; Huyut et al., 2018; Sekeroglu et al., 2017). In other studies, it was shown that the supplementary UDSE helped to prevent the aflatoxininduced increase in the MDA of the liver and increased a hepatoprotective effect in the pathologic examinations. (Gülçin et al., 2004; Uyar, Yener, Dogan, 2016). We observed that the MDA level and lipid peroxidation increased in only the irradiated groups. On the other hand, UDSE treatment decreased the MDA concentrations to the control level, which showed that UDSE may be successful in inhibiting lipid peroxidation, and thereby may protect the membrane lipids from oxidative damage, as was found similarly in previous study (Uyar, Yener, Dogan, 2016 ).

As an alternative radioprotector, herbal medicines are generally considered a well-known form of complementary therapeutic strategy. Researchers have focused on herbal medicines, which have gained increasing importance to eliminate side effects of irradiation (Jagetia, Baliga, 2002). UD or nettle has more powerful antioxidant properties than well-known antioxidants, such as butylated hydroxytoluene (BHT), butylated hydroxyanisole (BHA), vitamin $E$ and quercetin (Gülçin et al., 2004). UD presents scavenging activity against the iron-promoted oxidation of phospholipids, deoxyribose, and linoleic acid (Matsingou, Kopsakefalou, Salifoglou, 2001). When the electrogenerated bromine technique was used to estimate the antioxidant capacity of UD and plant-based medicinal preparations, it was shown that UD prevented damage from rat liver tissue.

There is a balance between ROS production and the antioxidant defence system in healthy individuals. The free radical scavenging activity of antioxidant defensive systems could be adversely affected by formed ROS with radiotherapy (Yu, 1994). GSH, GSH-Px, CAT, and glutathione S-transferase (GST) are among the major intracellular antioxidant defence systems that eliminate lipid peroxides and free oxygen radicals (Trakshel, Maines, 1988). In an previous study, it was reported that UD extract increases SOD, CAT, and GST activities at varying rates (Celik, Tuluce, 2007). Ekici et al. have shown that oxidative stress and the stress index were significantly increased and the SOD, CAT, and GSH levels or activities were decreased when compared to the control group in the kidney and testis tissues of male rats treated with 800 cGray radiation (Ekici et al., 2016).

In our study, the SOD activity of both serum and liver tissue samples in the R group was the lowest, while it was highest in the UDSE group $(\mathrm{P}<0.05)$. In addition, the SOD activities of the R+UDSE group were similar to those in the $\mathrm{C}$ group $(\mathrm{P}>0.05)$.

The CAT activity and GSH levels in the serum samples of the R group were lower than those in the other groups $(\mathrm{P}<0.05)$. In addition, although the $\mathrm{CAT}$ activity and GSH values of the R group in the liver tissue samples were lower than those in the other groups, they were not significantly different $(\mathrm{P}>0.05)$. Additionally, there were no differences between the CAT and GSH levels in the serum samples of the $\mathrm{C}$ and R+UDSE groups.

In the liver samples, the GSH-Px activities in the $\mathrm{R}$ group were lower than those in the other groups. The GSH-Px levels in the R+UDSE, UDSE and C groups were similar $(\mathrm{P}<0.05)$. Moreover, the GSH-Px activities in the serum samples were higher in the UDSE group than that in all of the other groups, while they were lowest in the $\mathrm{R}$ group $(\mathrm{P}<0.05)$.

The results of the current study show that antioxidant enzyme activities, such as CAT, and especially SOD and GSH-Px, were significantly decreased in the serum and liver tissues of the groups exposed to radiation, whereas

TABLE I - Protective effects of UDSE on selected antioxidant enzyme activities and AST, ALT, MDA levels in the serum of rats

\begin{tabular}{|c|c|c|c|c|c|c|c|}
\hline Groups & $\begin{array}{c}\text { AST } \\
(\mathbf{I U} / \mathbf{L})\end{array}$ & $\begin{array}{c}\text { ALT } \\
(\text { IU/L) }\end{array}$ & $\begin{array}{c}\begin{array}{c}\text { Serum } \\
(\mathrm{MDA}) \\
(\mu \mathrm{M} / \mathbf{m L})\end{array} \\
\end{array}$ & $\begin{array}{l}\text { Serum } \\
(\mathrm{SOD}) \\
(\mathrm{ng} / \mathrm{mL})\end{array}$ & $\begin{array}{l}\text { Serum } \\
\text { (CAT) } \\
(\text { IU/mL) }\end{array}$ & $\begin{array}{l}\text { Serum } \\
(\mathrm{GSH}) \\
(\mathrm{mg} / \mathrm{dL}) \\
\end{array}$ & $\begin{array}{c}\text { Serum } \\
\text { (GSH-Px) } \\
(\mathrm{IU} / \mathbf{m L})\end{array}$ \\
\hline $\mathbf{R}$ & $120.5 \pm 6.2 *$ & $71.00 \pm 11^{*}$ & $3.00 \pm 0.52 *$ & $4.74 \pm 0.19^{\neq}$ & $2.50 \pm 0.1^{*}$ & $0.84 \pm 0.03 *$ & $44.07 \pm 2.7^{*}$ \\
\hline R+UDSE & $89.8 \pm 7.2^{*}$ & $61.2 \pm 7.5^{\theta}$ & $2.51 \pm 0.2^{\neq}$ & $4.97 \pm 0.30$ & $3.36 \pm 0.2$ & $1.06 \pm 0.07^{\theta}$ & $50.40 \pm 1.6^{*}$ \\
\hline
\end{tabular}

The data with symbol are significantly different $(\mathrm{P}<0.05)$, according to the Tukey T test. $(* \mathrm{p}<0.05)$ : according to the other groups, $\left({ }^{\neq} \mathrm{p}<0.05\right)$ : according to the $\mathrm{C}$ and UDSE groups, $\left({ }^{\phi} \mathrm{p}<0.05\right)$ : according to the $\mathrm{R}$ and $\mathrm{R}+\mathrm{UDSE}$ groups, $\left({ }^{\theta} \mathrm{p}<0.05\right)$ : according to the $\mathrm{R}$ and UDSE groups, AST: aspartate aminotransferase; ALT: alanine aminotransferase; MDA: malondialdehyde: SOD: superoxide dismutase; CAT: catalase; GSH: reduced glutathione; GSH-Px: glutathione peroxidase; Groups: C; control, R; radiation group, R+UDSE; radiation+ Urtica dioica seed extract group, UDSE; Urtica dioica seed extract group. 
TABLE II - Actions of UDSE on selected antioxidant enzyme activities and MDA in the liver tissue of rats

\begin{tabular}{|c|c|c|c|c|c|}
\hline Groups & $\begin{array}{c}\text { Liver } \\
\text { MDA } \\
\text { (nmol/mg protein) } \\
\end{array}$ & $\begin{array}{c}\text { Liver } \\
\text { (SOD) } \\
\text { (IU/mg protein) } \\
\end{array}$ & $\begin{array}{c}\text { Liver } \\
\text { (CAT) } \\
\text { (IU/mg protein) }\end{array}$ & $\begin{array}{c}\text { Liver } \\
\text { (GSH) } \\
\text { (mg/mg protein) }\end{array}$ & $\begin{array}{c}\text { Liver } \\
\text { (GSH-Px) } \\
\text { (IU/mg protein) }\end{array}$ \\
\hline $\mathrm{C}$ & $3.58 \pm 0.42$ & $2.53 \pm 0.15$ & $0.73 \pm 0.10$ & $2.08 \pm 0.25$ & $4.18 \pm 0.46$ \\
\hline $\mathbf{R}$ & $3.86 \pm 0.21^{*}$ & $2.28 \pm 0.20^{\neq}$ & $0.68 \pm 0.05$ & $1.95 \pm 0.12$ & $3.85 \pm 0.12 *$ \\
\hline R+UDSE & $3.59 \pm 0.19$ & $2.37 \pm 0.07$ & $0.71 \pm 0.07$ & $2.01 \pm 0.15$ & $3.92 \pm 0.19$ \\
\hline UDSE & $3.43 \pm 0.16$ & $2.67 \pm 0.25$ & $0.75 \pm 0.05$ & $2.13 \pm 0.12$ & $4.26 \pm 0.21^{\phi}$ \\
\hline
\end{tabular}

The Values with sign are significantly different $(\mathrm{P}<0.05)$, according to the Tukey $\mathrm{T}$ test. $\left({ }^{*} \mathrm{p}<0.05\right)$ : according to the other groups, $\left({ }^{\neq} \mathrm{p}<0.05\right)$ : according to the $\mathrm{C}$ and UDSE groups, $\left({ }^{\dagger} \mathrm{p}<0.05\right)$ : according to the $\mathrm{R}$ and $\mathrm{R}+\mathrm{UDSE}$ groups. AST: aspartate aminotransferase; ALT: alanine aminotransferase; MDA: malondialdehyde: SOD: superoxide dismutase; CAT: catalase; GSH: reduced glutathione; GSH-Px: glutathione peroxidase; Groups: C; control, R; radiation group, R+UDSE; radiation+ Urtica dioica seed extract group, UDSE; Urtica dioica seed extract group.

TABLE III - Observational comparison of the effects of UDSE and radiation on the hepatic structure formation

\begin{tabular}{lccccc}
\hline Lesions (Liver) & $\mathrm{C}$ & $\mathrm{R}$ & $\mathrm{R}+$ UDSE & UDSE & $\mathrm{p}$ Value \\
\hline Degeneration & $-8^{\mathrm{b}}$ & $8 / 8^{\mathrm{b}}$ & $2 / 8^{\mathrm{b}}$ & $-/ 8^{\mathrm{b}}$ & $*$ \\
Slight & - & 7 & 2 & - & \\
Moderate & - & 1 & & - & $*$ \\
\hline Proliferation in perisinusoidal cells & $-8^{\mathrm{b}}$ & $8 / 8^{\mathrm{a}}$ & $4 / 8^{\mathrm{ab}}$ & $-/ 8^{\mathrm{b}}$ & $*$ \\
Slight & - & 7 & 4 & - & $*$ \\
Moderate & - & 1 & & $-/ 8^{\mathrm{b}}$ & $*$ \\
\hline Necrosis & $-/ 8^{\mathrm{b}}$ & $8 / 8^{\mathrm{a}}$ & $1 / 8^{\mathrm{b}}$ & - & \\
Slight & - & 7 & 1 & - & \\
Moderate & - & 1 & - & & \\
\hline
\end{tabular}

a,b: Values with different letters in same row are significantly different, $*(\mathrm{P}<0.05), * *(\mathrm{P}<0.01)$. According to the chi-square test range". Groups: C; control, R; radiation, R+UDSE; radiation+ Urtica dioica seed extract, UDSE; Urtica dioica seed extract.

there were no significant changes in the activities of these enzymes and GSH levels in the R+UDSE group when compared with the $\mathrm{C}$ group.

\section{Histopathological findings}

Normal histological findings were observed in the liver tissues samples in the $\mathrm{C}$ groups (Figure $2 \mathrm{~A}$ ). In the $\mathrm{R}$ group, degenerative and necrotic changes were detected in the majority of the liver lobules, especially in the periacinar hepatocytes (stars). The integrity of these hepatocytes was impaired, the cytoplasm was pale in colour, and the nuclei had a pyknotic or fragmented appearance (arrows). Due to these degenerative-necrotic changes in the hepatocytes, the structure of the remark cords was corrupted (dissociated) (Figure 2 B). In addition, the hyperaemia in the venules and the activation of the perisinusoidal cells were noted. In the R+UDSE group, when compared with the control group, almost normal histological appearances were observed. In the UDSE group, normal histological findings were found in the liver tissue samples (Figure 2 D).

In recent years, significant hepatic lesions have been detected from the histopathological examinations related to irradiation in the abdominal region. The liver is a relatively more radiosensitive organ and radiation treatment causes many significant changes in the metabolic functions of the liver (Barshishat-Kupper et al., 2014). Some radio-protective agents have been used prior to irradiation to prevent the harmful effects of radiation on healthy tissues or cells, and many studies have reported that the use of these agents had a radio-protective effect on the kidney and liver (Jirtle, Anscher, Alati, 1990).

Recent histopathological studies have shown that radiation exposure to liver tissue can cause swelling in hepatocytes, deterioration of the membrane structure, and sinusoidal dilatation. However, it was proven that antioxidant treatment together with radiation protected the liver tissues and showed a healthy structure similar to that of the control group (Das et al., 2014). Our findings 

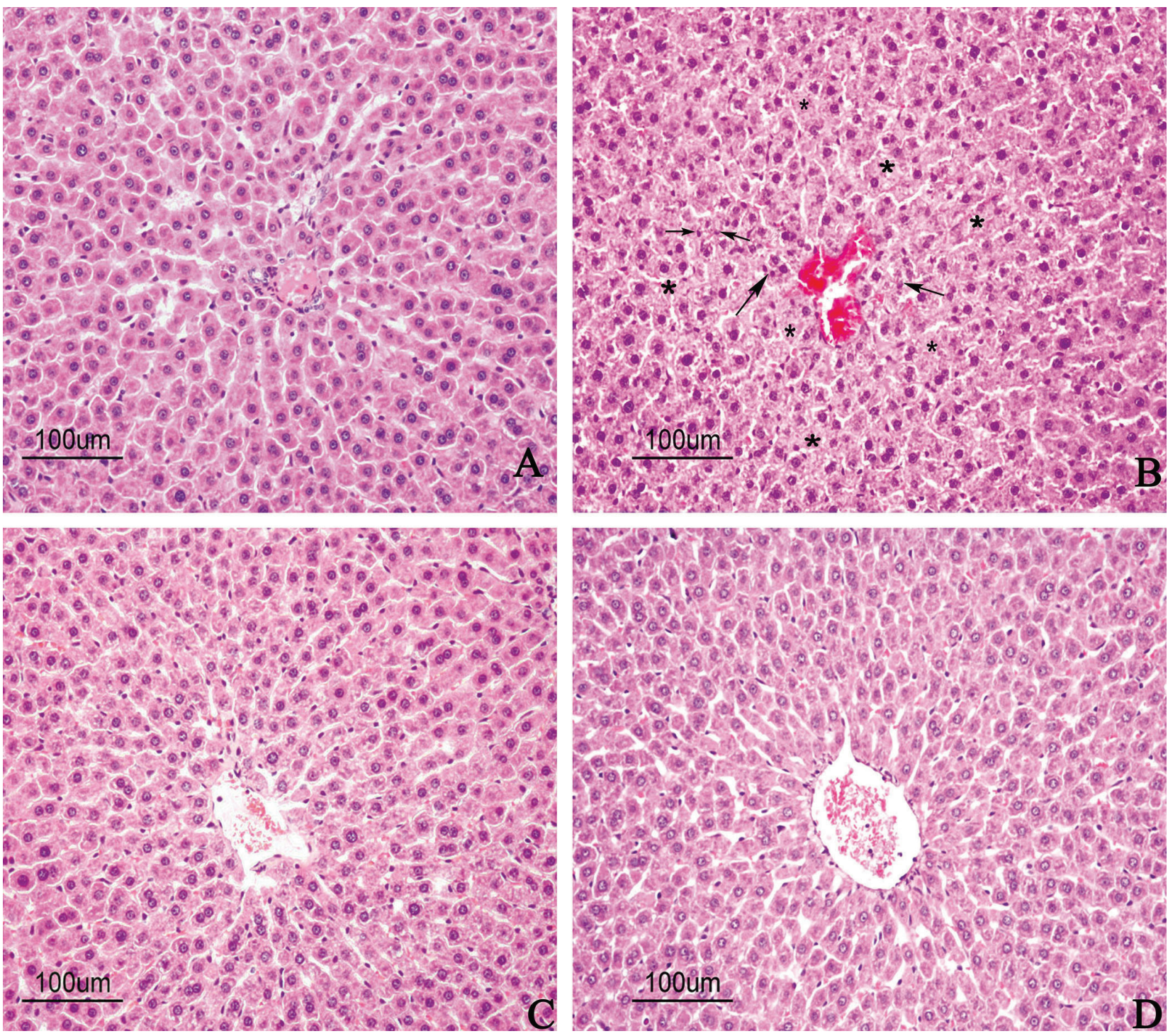

FIGURE 2 - (A) Liver of the rats shows normal architecture of lobules from the C group, (B) Hepatocytes in the periacinar and midzonal regions are swollen, their cytoplasm is stained in a pale color and appear as fine granular or homogeneous $\left({ }^{*}\right)$. In addition, the nuclei of some hepatocytes are dark color and picnotical $(\longrightarrow$ ) from the R group, $(\mathrm{C})$ Parenchymal degeneration is observed in some hepatocytes in the periacinar (*) from the R+UDSE group and (D) liver of rats shows normal architecture of lobules from the UDSE group. Groups: C; control, R; radiation, R+UDSE; radiation+ Urtica dioica seed extract, UDSE; Urtica dioica seed extract. (haematoxylin-eosin, bar: $100 \mu \mathrm{m}$.).

have supported previous studies and showed that the use of UDSE together with radiotherapy decreased the harmful and destructive effects of irradiation in liver tissue.

\section{CONCLUSION}

These data show that UDSE prevents radiotherapyinduced liver damage, lipid peroxidation and oxidative stress, and protects antioxidant enzyme activities. For this reason, UDSE may be used as a radioprotector after irradiation. In addition, this study has indicated that local radiation therapy may be a more beneficial model than whole-body radiation therapy. However, future studies with different local or mimic radiation models are needed to test whether UDSE protects tumours or healthy cells from radiation.

\section{ACKNOWLEDGMENTS}

This study is part of a research project funded by the Research Foundation of the Van Yuzuncu Y1l University Scientific Research Projects Coordination Unit, under No: 2016-VF-B003. 


\section{CONFLICTS OF INTEREST}

The authors declared that there are no potential conflicts of interest with respect to the research, authorship, and/or publication of this article.

\section{FUNDING}

This study was supported with the aid of the Department of Biochemistry, Faculty of Medicine and the Department of Pathology, Faculty of Veterinary, at the Van Yuzuncu Yil University

\section{REFERENCES}

Akbay P, Basaran AA, Undeger U, Basaran N. In vitro immunomodulatory activity of flavonoid glycosides from Urtica dioica L. Phytother Res. 2003;17(1):34-37.

Alizadeh E, Sanz AG, Garcia G, Sanche L. Radiation damage to DNA: The indirect effect of low-energy electrons. J Phys Chem Lett. 2013;4(5):820-825.

Barshishat-Kupper M, Tipton AJ, McCart EA, McCue J, Mueller GP, Day RM. Effect of ionizing radiation on liver protein oxidation and metabolic function in $\mathrm{C} 57 \mathrm{BL} / 6 \mathrm{~J}$ mice. Int J Radiat Biol. 2014;90(12):1169-1178.

Celik I, Tuluce Y. Elevation protective role of Camellia sinensis and Urtica dioica infusion against trichloroacetic acid-exposed in rats. Phytother Res. 2007;21(11):1039-44.

Das U, Manna K, Sinha M, Dattla S, Das DK, Chakraborty A, Ghosh M, Saha KD, Dey S. Role of ferulic acid in the amelioration of ionizing radiation induced inflammation: a murine model. PLoS One. 2014;9(5):e97599.

Ekici K, Temelli O, Parlakpinar H, Samdanci E, Polat A, Beytur A, Tanbek K, Ekici C, Dursun IH. Beneficial effects of aminoguanidine on radiotherapy-induced kidney and testis injury. Andrologia. 2016;48(6):683-692.

Goth L. A simple method for determination of serum catalase activity and revision of reference range. Clin Chim Acta. 1991;196(2-3):143-151.

Gumustekin K, Taysi S, Alp HH, Aktas O, Oztasan N, Akcay F, Suleyman H, Akar S, Dane S, Gul M. Vitamin E and Hippophea rhamnoides L. extract reduce nicotine-induced oxidative stress in rat heart. Cell Biochem Funct. 2010;28(4):329-333.
Gülçin I, Küfrevioğlu Öİ, Oktay M, Büyükokuroğlu ME. Antioxidant, antimicrobial, antiulcer and analgesic activities of nettle (Urtica dioica L.). J Ethnopharmacol. 2004;90(23):205-215.

Hajhashemi V, Klooshani V. Antinociceptive and antiinflammatory effects of Urtica dioica leaf extract in animal models. Avicenna J Phytomed. 2013;3(2):193-200.

Halliwell B. Free radicals, reactive oxygen species and human disease: a critical evaluation with special reference to atherosclerosis. Br J Exp Pathol. 1989;70(6):737-757.

Huyut Z, Şekeroğlu MR, Balaharoğlu R, Karakoyun T, Çokluk E. The Relationship of Oxidation sensitivity of red blood cells and carbonic anhydrase activity in stored human blood; effect of certain phenolic compounds. BioMed Res Int. 2016;2016:3057384.

Huyut Z, Şekeroğlu MR, Balahoroğlu R and Huyut MT. Characteristics of resveratrol and serotonin on antioxidant capacity and susceptibility to oxidation of red blood cells in stored human blood in a time-dependent manner. J Int Med Res. 2018;46(1):272-283.

Jaffray DA, Gospodarowicz MK. Radiation therapy for cancer. Disease Control Priorities Third Edition. Washington, D.C. : The World Bank; 2015.

Jagetia GC, Baliga MS. Syzygium cumini (Jamun) reduces the radiation-induced DNA damage in the cultured human peripheral blood lymphocytes: a preliminary study. Toxicol Lett. 2002;132(1):19-25.

Jirtle RL, Anscher MS, Alati T. Radiation sensitivity of the liver. Adv Radiat Biol. 1990;14:269-311.

Kav S, Pinar G, Gullu F, Turker T, Elibol S, Dogan N, Algier L. Use of complementary and alternative medicine in patients with gynecologic cancer: is this usage more prevalent? J Alt Comp Med. 2008;14(4):347-352.

Kavalali G, Oztekin-Mat A. European pharmaceutical patent medicines delivered by the dispensaries of Istanbul, Turkey in 1850. Rev Hist Pharm. 1996;44:383-384.

Khoschsorur G, Winklhofer-Roob B, Rabl H, Auer T, Peng Z, Schaur RJ. Evaluation of a sensitive HPLC method for the determination of malondialdehyde, and application of the method to different biological materials. Chromatographia. 2000; 52(3-4):181-184. 
Körpe DA, İşeri ÖD, Sahin FI, Cabi E, Haberal M. Highantibacterial activity of Urtica spp. seed extracts on food and plant pathogenic bacteria. Int J Food Sci Nutr. 2013;64(3):355362.

Kushi LH, Byers T, Doyle C, Bandera EV, McCullough M, McTiernan A, et al. American Cancer Society Guidelines on Nutrition and Physical Activity for cancer prevention: reducing the risk of cancer with healthy food choices and physical activity. CA Cancer J Clin. 2006;56(5):254-281.

Lou YR, Lu YP, Xie JG, Huang MT, Conney HA. Effects of oral administration of tea, decaffeinated tea, and caffeine on the formation and growth of tumors in high-risk SKH-1 mice previously treated with ultraviolet B light. Nutr Cancer. 1999;33(2):146-153.

Matsingou T, Kapsokefalou M, Salifoglou A. Aqueous infusions of Mediterranean herbs exhibit antioxidant activity towards iron promoted oxidation of phospholipids, linoleic acid, and deoxyribose. Free Radic Res. 2001;35(5):593-605.

Perez C, Fields J. Role of radiation therapy for locally advanced and inflammatory carcinoma of the breast. Oncology. 1987;1(1):81-94.

Song LH, Yan HL, Cai DL. Protective effects of soybean isoflavone against gamma-irradiation induced damages in mice. J Radiat Res 2006;47(2):157-165.

Srinivasan M, Devipriya N, Kalpana K, Menon VP. Lycopene: an antioxidant and radioprotector against $\gamma$-radiation-induced cellular damages in cultured human lymphocytes. Toxicology 2009;262(1):43-49.

Sun Y, Oberley LW, Li Y. A simple method for clinical assay of superoxide dismutase. Clin Chem. 1988;34(3):497-500.
Şekeroğlu MR, Huyut Z, Çokluk E, Özbek H, Alp HH. The susceptibility to autoxidation of erythrocytes in diabetic mice: Effects of melatonin and pentoxifylline. J Biochem Mol Toxicol. 2017;31(12):e21976.

Taysi S, Memisogullari R, Koc M, Yazici AT, Aslankurt M, Gumustekik K, et al. Melatonin reduces oxidative stress in the rat lens due to radiation-induced oxidative injury. Int J Radiat Biol. 2008;84(10):803-808.

Telo S, Halifeoglu I, Ozercan IH. Effects of stinging nettle (Urtica Dioica L.,) on antioxidant enzyme activities in Rat Model of mammary gland cancer. Iran J Pharm Res. 2017;16(Suppl):164-170.

Trakshel GM, Maines MD. Characterization of glutathione S-transferases in rat kidney. Alteration of composition by cisplatinum. Biochem J. 1988;252(1):127-136.

Uyar A, Yener Z, Dogan A. Protective effects of Urtica dioica seed extract in aflatoxicosis: histopathological and biochemical findings. Br Poult Sci. 2016;57(2):235-245.

Valentine WN, Paglia DE. Studies with human erythrocyte pyruvate kinase (PK): effects of modification of sulfhydryl groups. Br J Haematol. 1983;53(3):385-398.

Yener Z, Celik I, Ilhan F, Bal R. Effects of Urtica dioica L. seed on lipid peroxidation, antioxidants and liver pathology in aflatoxin-induced tissue injury in rats. Food Chem Toxicol. 2009;47(2):418-424.

Yu BP. Cellular defenses against damage from reactive oxygen species. Physiol Rev. 1994;74(1):139-163.

Received for publication on $04^{\text {th }}$ May 2018 Accepted for publication on $23^{\text {rd }}$ September 2018 